\title{
Investigation of Genetic Diversity in Fusarium Wilt of Egg Plant Caused by Fusarium oxysporum f.Sp. melangene (Schlecht) Mutuo and Ishigami in Marathwada Region of Maharastra, India
}

\author{
V. Govardhan Rao ${ }^{1 *}$, D.N. Dhutraj ${ }^{3,4}$, S.R. Bhalerao ${ }^{2}$, K.T. Apet ${ }^{4}$, \\ C.V. Ambadkar ${ }^{4}$, B. Prasanna Kumar ${ }^{1}$, A. T. Daunde ${ }^{2}$, P.L. Sontakke ${ }^{4}$ and A.G. Patil ${ }^{4}$ \\ ${ }^{1}$ Department of Plant Pathology, College of Horticulture, Dr. YSRHU, \\ Parvathipuram, (A.P), India-535 501 \\ ${ }^{2}$ Department of Plant Biotechnology, ${ }^{3}$ Vilasrao Deshmukh College of Agricultural \\ Biotechnology, VNMKV, Latur (MS), India-413512 \\ ${ }^{4}$ Department of Plant Pathology, VNMKV, Parbhani (MS), India-431 401 \\ *Corresponding author
}

\section{A B S T R A C T}

\begin{tabular}{|c|c|}
\hline $\begin{array}{l}\text { Ke y w o r d s } \\
\text { Fusarium } \\
\text { oxysporum, Egg } \\
\text { plant, FOM }\end{array}$ & $\begin{array}{l}\text { The experiments described in this chapter were conducted during the Kharif-2018-19.The } \\
\text { RAPD marker can be used to find out diversity among different isolates of Fusarium } \\
\text { oxysporum f.sp. melongenae. The highest genetic similarity to the extent of } 0.58 \text { (i.e. } 58 \% \text { ) } \\
\text { was recorded between FOM- } 2 \text { and FOM- } 7 \text {. This indicates that FOM-2 and FOM-7 isolates } \\
\text { of Fusarium oxysporum f.sp. melongenae were showing maximum similarity based on }\end{array}$ \\
\hline Article Info & selected RAPD primers. Whereas, FOM- 1 and FOM- 5 were found least genetic similar \\
\hline $\begin{array}{l}\text { Accepted: } \\
10 \text { June } 2019 \\
\text { Available Online: } \\
10 \text { July } 2019\end{array}$ & $\begin{array}{l}\text { mentioned in description were found to be different from each other. It states that the } \\
\text { isolates show diversity among each other. The genetic variability in the FOM isolates may } \\
\text { be due to differences in geographical and environmental conditions. }\end{array}$ \\
\hline
\end{tabular}

\section{Introduction}

Vegetables play an important role in human nutrition and health by providing minerals, micronutrients, vitamins, antioxidants and dietary fiber. Vegetables cultivation is significant part of the national agriculture economy, especially in developing world. Brinjal (Solonum melongenae) also known as eggplant is a common and popular vegetables crop grown in the subtropics and tropics. Its belong to family 'Solanacae' it is one of the widely used vegetables crops by most of the people and is popular in many countries viz. central south and south east Asia, some parts of Africa and central America (Harish et al., 2011) It is grown in 691,000 hectares with production of eight production of eight to nine 
million tonnes (equivalent to one quarter of global production), which makes India the second largest producer of brinjal in the world. In India, brinjal is cultivated in 729 hectares with a total production of about 12616 million tonnes. The major brinjal producing states in India are Andhra Pradesh, Maharashtra, Karnataka, Orissa, Madhya Pradesh and West Bengal (IKISAN 2018).

\section{Fusarium oxysporum f.sp. melongenae}

Brinjal is susceptible to many diseases like verticillium wilt (Verticillium dahliae), Fusarium wilt (Fusarium oxysporum f. sp. melongenae) and bacterial wilt (Ralstonia solanacearum) (Kalloo and Berg, 1993) and (Sihachakr et al., 1994). Fusarium wilt, caused by Fusarium oxysporum f. sp. melongenae, is a major constraint in brinjal production in India. The disease is widely distributed in tropical, subtropical and some warm temperate regions of the world. The pathogen is difficult to control since it is soilborne and has a wide host-range, including several hundred species representing 44 families of plants. Infection is through rootto-root transmission, movement of soil and dissemination by farm implements, and insect transmission. A combination of high temperature and poor drainage favor development of the disease which causes 75 to $81 \%$ yield loss during summer in India (Das and Chattopadhyay, 1953; Rai et al., 1975; Rao et al., 1976).

Fusarium wilt in brinjal is being managed by application of bactericides, copper fungicides and by crop rotation, with no adequate control. Once the disease develops and wilt symptoms appear in the field, application of bactericides and copper fungicides has no effect on the bacterium. Crop rotation is not a viable control method, as; the bacteria can persist indefinitely in infested fields (Jaworski and Morton, 1964; Sonoda, 1978). In the absence of effective chemicals and bactericides for managing this disease, emphasis is laid on developing brinjal (brinjal) cultivars with resistance to Fusarium oxysporum. Though resistance to Fusarium wilt has been studied in several crops, especially tomato, there is little published work on Fusarium wilt resistance in brinjal (Chaudhary and Sharma, 2000; Zakir Hussain et al., 2005; Mondal et al., 2013).

\section{Molecular markers}

The recent development of random amplified polymorphic DNA (RAPD) has allowed a rapid generation of reliable reproducible DNA fragment that showed of great use in identifying pathogenic variation in several fungal plant pathogens (Jimenez-Gasco et al., 2001).

The main objectives of this work were to determine if RAPDs could be of useful for the characterization of pathotypes and races of Fusarium oxysporum f. sp. melongenae isolates infecting Brinjal. The present study is with an objective to investigate genetic diversity in fusarium wilt of egg plant caused by Fusarium oxysporum f.Sp. melangene (Schlecht) Mutuo and Ishigami in Marathwada region of Maharastra.

\section{Materials and Methods}

The present study "Investigation of Genetic Diversity of Fusarium oxysporum f. sp. melongenae Causing Wilt Disease In Brinjal By RAPD Marker" was carried out at the Department of Plant Biotechnology, Vilasrao Deshmukh College of Agricultural Biotechnology, Latur, Vasantrao Naik Marathwada Krishi Vidyapeeth, Parbhani during the year 2018-2019. The details of field and laboratory procedure followed during this research work are described in this chapter. 


\section{Collection of diseased samples}

Eight wilt affected Eggplant samples were collected from different regions of Maharashtra (Fig. 1).

These diseased samples were preserved at $4^{\circ} \mathrm{C}$ in refrigerator and used for further studies.

\section{Sterilization of root sample}

The infected root samples were surface sterilized with $0.1 \%$ Mercuric chloride $\left(\mathrm{HgCl}_{2}\right)$ for $30 \mathrm{sec}$. and washed 3-4 times with sterilized double distilled water to remove traces of $\mathrm{HgCl}_{2}$. The surface sterilized root samples were then placed on PDA medium containing streptomycin $(0.12 \mathrm{gm} / \mathrm{lit})$ and incubated at $26^{\circ} \mathrm{C}$ for 5-6 days.

\section{Purification of the Fusarium oxysporum $\mathbf{f}$.} sp. melongenae isolates

All the isolates of the pathogen were purified by hyphal tip method (Dohroo and Shanna, 1992). Sufficient care was taken to maintain the purity of the isolates throughout the study.

\section{Morphological characterization}

To study morphology of macroconidia, microconidia and chlamydospore 10-15 day old culture of each isolate grown on PDA medium was stained with $0.1 \%$ Lactophenol cotton blue on slide and observed under compound microscope.

\section{Genetic variability}

Random amplified polymorphic DNA (RAPD) marker was used to detect the variations among the isolates of Fusarium oxysporum f. sp. melongenae. Standardized protocol was used for the isolation of DNA and RAPD analysis (Williams et al., 1990).

\section{DNA isolation}

The standardized protocol of Cenis (1992) for DNA extraction was used with some modifications and yielded sufficient quantity of DNA which was amenable to PCR amplification.

\section{Extraction of genomic DNA}

One week old mycelial mat was filtered through Whatmann No.1 filter paper and air dried.

Mycelium (0.5gm) was transferred to a sterile mortar pestle and ground with glass wool.

$1 \mathrm{ml}$ extraction buffer was added to the mortar and the content transferred to the $1.5 \mathrm{ml}$ centrifuge tube.

$200 \mu 1$ of $3 \mathrm{M}$ Sodium acetate $(\mathrm{pH}-5.2)$ was added and tubes were placed at $-20^{\circ} \mathrm{C}$ for 30 minutes.

Tubes were centrifuged at $13000 \mathrm{rpm}$ for 5 minutes and supernatant was transferred to another tube.

Equal volume of Isopropanol was added. The DNA in each tube was precipitated by incubating the mixture at room temperature for 5 minutes.

The precipitated DNA was pelleted by centrifugation in a microfuge tube at $13000 \mathrm{rpm}$ for 10 minutes.

The pellet was rinsed with $70 \%$ ethanol and air dried.

The pellet was re-suspended in $50 \mu 1$ of $\mathrm{TE}$ buffer.

\section{Purification of DNA}

\section{RNase treatments}

To degrade RNA present in DNA sample $1 \mu 1$ of RNase A $(10 \mathrm{mg} / \mathrm{ml})$ was added in DNA sample solution and incubated it at $37^{\circ} \mathrm{C}$ for 1 hour in water bath. 


\section{Dilution of DNA samples}

A part of DNA sample was diluted with appropriate quantity of sterilized double distilled water to yield a working concentration of $30 \mathrm{ng} / \mu \mathrm{l}$ and stored at $4^{\circ} \mathrm{C}$ until PCR amplification.

\section{Agarose gel electrophoresis}

The gel electrophoresis unit was, cleaned properly before use $0.8 \%$ Agarose gel was prepared by dissolving $0.8 \mathrm{~g}$ of Agarose in $100 \mathrm{ml} 1 \mathrm{X}$ TAE buffer and heated in microwave oven and $5 \mu 1$ Ethidium bromide $(10 \mathrm{mg} / \mathrm{ml})$ was added to it after cooling down to $45^{\circ} \mathrm{C}$. The gel was then poured in mini casting tray in which comb was inserted previously and kept for 1 hour. After solidification the comb was removed. $5 \mu 1$ of DNA was mixed with $2 \mu 11 \mathrm{X}$ gel loading dye and loaded on the gel. The electrophoresis was carried out at $100 \mathrm{~V}$ for 1.5 hours using $1 \mathrm{X}$ TAE buffer.

\section{DNA fingerprinting profile}

The RAPD-PCR protocol was used with some modifications to produce DNA fingerprinting profile of 8 fungal isolates of Fusarium oxysporum f. sp. melongenae (Table 1 and Fig. 2-8).

The PCR amplification reaction was optimized by varying concentration of PCR components. Amplification reaction was carried out in $25 \mu \mathrm{l}$ reaction mixtures containing $30 \mathrm{ng}$ of fungal genomic DNA, 1X PCR buffer, $1.5 \mathrm{mM} \mathrm{MgCl}_{2}, 0.25 \mathrm{mM}$ dNTPs, 10 pmol primers and $1.50 \mathrm{U}$ of Taq DNA polymerase. PCR amplification was performed in master cycler gradient, Eppendorf PCR thermocycler, and the program consisted of an initial denaturing at $94{ }^{\circ} \mathrm{C}$ for $4 \mathrm{~min}$, followed by 39 cycles comprising denaturation at $94{ }^{\circ} \mathrm{C}, 1 \mathrm{~min}$, annealing at $37{ }^{\circ} \mathrm{C}$ and extension of $2 \mathrm{~min}$. at $72{ }^{\circ} \mathrm{C}$. The final extension was set at $72{ }^{\circ} \mathrm{C}$ for $10 \mathrm{~min}$. PCR amplified product was separated by electrophoresis on $1.5 \%$ agarose gel in $1 \mathrm{X}$ TAE buffer, stained with Ethidium bromide and visualized under gel documentation system.

\section{RAPD Analysis}

Five random primers viz., OPA-16, OPA-06, OPA-12, OPA-04, OPA-10, were screened which showed clear banding pattern, which are used for genetic diversity analysis of 8 FOM isolates. The PCR reactions were set in a $25 \mu$ reaction volume.

\section{PCR reaction}

Master mix was prepared with the above mentioned reagents and divided into 8 equal parts (each of $24 \mu \mathrm{l}$ ) into 8 different PCR tubes. $1 \mu 1$ of 8 different genomic DNA samples of fungal isolates was added to master mix by changing tips to avoid contamination that leads to final quantity of $25 \mu 1$. PCR tubes were then placed in thermal cycler for amplification of the genomic DNA as per the standardized protocol by Williams et al., (1990) with some modifications according to selected primers.

\section{Resolution of amplified product}

The amplified products were resolved on $1.5 \%$ Agarose gel at 60 volts for appropriate hours. The gel was stained with Ethidium bromide $(5 \mu 1 / 100 \mathrm{ml})$. After electrophoresis, the gel was carefully removed from the casting tray and photograph was taken on a Gel documentation system (Alphaimager).

\section{Data scoring and analysis}

Amplified products in the gel images were scored for presence (1) or absence (0) missing 
and doubtful case were scored as 9 . Homology of bands based on the distance of migration of amplified DNA fragments according to their molecular weights in the gel was determined. Molecular weights of the bands were estimated using 100 bp DNA ladder as standard. Data analysis was performed using NTSYS-PC (Numerical Taxonomy System) Version 2.02 software (Rohlf, 1990).

\section{Results and Discussion}

The results of present study entitled Investigation of genetic diversity in fusarium wilt of egg plant caused by Fusarium oxysporum f.Sp. melangene (Schlecht) Mutuo and Ishigami in Marathwada region of Maharastra. studied 8 isolates belonging to different species of Fusarium oxysporum f. sp melongenae were subjected to amplification by RAPD. The data obtained from RAPD marker clearly distinguished the isolates of fungus used for study of genetic relationships. The marker method differentiated clusters within species. The results obtained in the study are presented under following headings.

Isolation and Identification of the Fusarium oxysporum f. sp. melongenae

Fusarium oxysporum f. sp. melongenae were isolated from the roots of wilted plants of Brinjal. Eight FOM isolates of Fusarium oxysporum f. sp. melongenae were obtained. Growth of fungus was observed 3-4 days after incubation at $27^{\circ} \mathrm{C}$ in all FOM isolates. The isolates were fluffy in its growth while the colour was dull white, pinkish white and pink depending upon the isolates (Fig. no.2).

On the basis of macroconidia, microconidia and chlymadosores the isolates were identified as Fusarium oxysporum f. sp. melongenae on the basis of morphological characteristics feature mentioned in the monograph by Booth (1971). The isolates were purified and mass multiplied for further studies.

\section{DNA extraction}

Genomic DNA of 8 Fusarium oxisporum f.sp. melongenae isolates was extracted from their mycelial mat grown on Potato dextrose broth by using protocol of Cenis (1992) with some modification and yielded 350-400ng/ $\mu \mathrm{l}$ quantity of DNA which was amenable to PCR amplification.

Genetic diversity analysis of Fusarium oxysporum f.sp. melongenae using RAPD Marker

The DNA fingerprint was generated through RAPD primer (OPA-04, OPA-10, OPA-12, OPA-16, and OPA-06) as shown in figure 4 to 8. Based on the fingerprint data polymorphism percentage for each RAPD primer was calculated for eight isolates of Fusarium oxysporum f. sp. melongenae.

\section{Percent Polymorphism $(\%)=$}

\section{No. of polymorphic bands $\times 100$ Total no. of bands}

Eight isolates of Fusarium oxysporum f. sp. melongenae were differentiated on the basis of their RAPD pattern. In all 47 bands were generated from 8 isolates using 5 arbitrary primers tested with an average of 9.4 bands per primer. The no. of amplified bands ranged from 5-13.

The primer OPA-10 produced lowest number of bands (05) whereas primer OPA-04 produced highest (13) bands. The most informative primer was OPA-04 with 13 polymorphic bands. In present study, the similarity coefficient value was ranged between 0.25 to 0.58 across eight isolates 
indicated existence of genetic variation among selected eight isolates of Fusarium oxysporum f.sp. melongenae. The highest genetic similarity to the extent of 0.58 (i.e. 58 $\%)$ was recorded between FOM-2 and FOM7. This indicates that FOM-2 and FOM-7 isolates of Fusarium oxysporum f.sp. melongenae were showing maximum similarity based on selected RAPD primers.
Whereas, FOM-1 and FOM-5 were found least genetic similar showing similarity 0.25 $(25 \%)$. The highest genetic distance was found in FOM-1 and FOM-5, they were 0.75 $(75 \%)$ diverse from each other. Least genetic distance was found in FOM-2 and FOM-7 which is $0.42(42 \%)$. Whereas FOM-2 and FOM-7 were found lowest genetic distance showing $0.42(42 \%)$ (Table 2-7).

Table.1 Isolates of Fusarium oxysporum. f. sp. melongenae collected from different regions of Marathwada

\begin{tabular}{|c|c|c|c|}
\hline Sr.No & Isolate Codes & District & Tashil \\
\hline FOM-1 & FOM A3 & Aurangabad & Soegaon \\
\hline FOM-2 & FOM B5 & Beed & Ambajogai \\
\hline FOM-3 & FOM H7 & Hingoli & Sengaon \\
\hline FOM-4 & FOM J10 & Jalna & Badnapur \\
\hline FOM-5 & FOM L14 & Latur & Chakur \\
\hline FOM-6 & FOM N16 & Nanded & Kinwat \\
\hline FOM-7 & FOM O20 & Osmanabad & Tuljapur \\
\hline FOM-8 & FOM P22 & Parbhani & Gangakhed \\
\hline
\end{tabular}

Table.2 List of primers used for RAPD analysis

\begin{tabular}{|c|c|c|c|}
\hline Sr. No. & Name of Primer & Sequence & Base pair \\
\hline $\mathbf{1}$ & OPA-16 & 5'AGCCAGCGAA3' & 10 \\
\hline $\mathbf{2}$ & OPA-06 & 5'GGTCCCTGAC3' & 10 \\
\hline $\mathbf{3}$ & OPA-12 & 5'ACGGTACCAGT3' & 10 \\
\hline $\mathbf{4}$ & OPA-04 & 5'CACCCCCTTG3' & 10 \\
\hline $\mathbf{5}$ & OPA-10 & 5'GTGATCGCAG3' & 10 \\
\hline
\end{tabular}

Table.3 Components of RAPD-PCR

\begin{tabular}{|c|c|c|c|}
\hline Sr. No. & PCR Components & Volume for 1 tube & Final Conc. \\
\hline $\mathbf{1}$ & PCR Buffer & $2.5 \mu \mathrm{l}$ & $10 \mathrm{X}$ \\
\hline $\mathbf{2}$ & $\mathrm{MgCl}_{2}$ & $2.0 \mu \mathrm{l}$ & $25 \mathrm{mM}$ \\
\hline $\mathbf{3}$ & $\mathrm{dNTPs}$ & $1.25 \mu \mathrm{l}$ & $10 \mathrm{mM}$ \\
\hline $\mathbf{4}$ & Primer & $1.0 \mu \mathrm{l}$ & $30 \mathrm{pmol}$ \\
\hline $\mathbf{5}$ & Taq DNA Polymerase & $0.33 \mu \mathrm{l}$ & $1 \mathrm{U}$ \\
\hline $\mathbf{6}$ & Template DNA & $1.0 \mu \mathrm{l}$ & $30 \mathrm{ng}$ \\
\hline $\mathbf{7}$ & Nuclease Free Water & $17.05 \mu \mathrm{l}$ & --- \\
\hline & Total Volume & $\mathbf{2 5 \mu l}$ & \\
\hline
\end{tabular}


Table.4 Temperature profile used for DNA amplification by RAPD Marker

\begin{tabular}{|c|c|c|c|c|}
\hline Sr. No. & Steps & Temperature $\left.\mathbf{(}^{\mathbf{0}} \mathbf{C}\right)$ & Duration & Cycle \\
\hline $\mathbf{1}$ & Initial Denaturation & 94 & $5 \mathrm{~min}$ & \\
\hline $\mathbf{2}$ & Denaturation & 94 & $1 \mathrm{~min}$ & \\
\hline $\mathbf{3}$ & Annealing & 36 & $1 \mathrm{~min}$ & 40 \\
\hline $\mathbf{4}$ & Primer Extension & 72 & $2 \mathrm{~min}$ & Cycles \\
\hline $\mathbf{5}$ & Final Extension & 72 & 10 & \\
\hline & & $\mathbf{H o l d}^{\mathbf{0}} \mathbf{C}$ & \\
\hline
\end{tabular}

Table.5 Percent polymorphism of RAPD primers for eight isolates of Fusarium oxysporum f.sp. melongenae

\begin{tabular}{|l|l|l|l|l|}
\hline $\begin{array}{l}\text { Primer } \\
\text { Name }\end{array}$ & No. of Bands & $\begin{array}{l}\text { No. of } \\
\text { Polymorphic } \\
\text { Bands }\end{array}$ & $\begin{array}{l}\text { No. of } \\
\text { Monomorphic } \\
\text { Bands }\end{array}$ & $\begin{array}{l}\text { \% } \\
\text { Polymorhpism }\end{array}$ \\
\hline OPA-16 & 11 & 8 & 3 & 72.72 \\
\hline OPA-10 & 5 & 4 & 1 & 80.00 \\
\hline OPA-12 & 12 & 11 & 1 & 91.66 \\
\hline OPA-06 & 6 & 6 & 0 & 100.00 \\
\hline OPA-04 & 13 & 13 & 0 & 100.00 \\
\hline Total & 47 & 42 & 5 & -- \\
\hline Average & 9.4 & 8.4 & 1 & $88.87 \%$ \\
\hline
\end{tabular}

Average percentage of polymorphism by RAPD marker: $88.87 \%$

Average number of bands amplified per primer: 9.4

Average number of polymorphic bands per primer: 8.4

Average number of Monomorphic bands: 1

Table.6 Jaccard' Similarity Matrix of eight isolates of Fusarium oxysporum f.sp. melongenae based on RAPD data

\begin{tabular}{|l|l|l|l|l|l|l|l|l|}
\hline \multicolumn{1}{|c|}{ Isolates } & FOM-A2 & FOM-B5 & $\begin{array}{c}\text { FOM- } \\
\text { H7 }\end{array}$ & FOM-J10 & FOM-L14 & FOM-N16 & FOM-O20 & FOM-P22 \\
\hline FOM-A2 & 1.00 & & & & & & & \\
\hline FOM-B5 & 0.37 & 1.00 & & & & & & \\
\hline FOM-H7 & 0.40 & 0.57 & 1.00 & & & & & \\
\hline FOM-J10 & 0.38 & 0.40 & 0.35 & 1.00 & & & & \\
\hline FOM- & 0.25 & 0.36 & 0.34 & 0.50 & 1.00 & & & \\
L14 & & & & & & & & \\
\hline FOM-16 & 0.39 & 0.50 & 0.31 & 0.56 & 0.51 & 1.00 & & \\
\hline FOM-20 & 0.32 & 0.58 & 0.45 & 0.51 & 0.55 & 0.53 & 1.00 & \\
\hline FOM-P22 & 0.31 & 0.51 & 0.39 & 0.42 & 0.48 & 0.56 & 0.55 & 1.00 \\
\hline
\end{tabular}


Table.7 Genetic distances between of eight isolates of Fusarium oxysporum f.sp. melongenae based on similarity index

\begin{tabular}{|l|l|l|l|l|l|l|l|l|}
\hline Isolates & FOM- & FOM- & FOM- & FOM- & FOM- & FOM- & FOM- & FOM- \\
& $\mathbf{1}$ & $\mathbf{2}$ & $\mathbf{3}$ & $\mathbf{4}$ & $\mathbf{5}$ & $\mathbf{6}$ & $\mathbf{7}$ & $\mathbf{8}$ \\
\hline FOM-A2 & 0.00 & & & & & & & \\
\hline FOM-B5 & 0.63 & 0.00 & & & & & & \\
\hline FOM-H7 & 0.60 & 0.43 & 0.00 & & & & & \\
\hline FOM-J10 & 0.62 & 0.60 & 0.75 & 0.00 & & & & \\
\hline FOM-L14 & 0.75 & 0.64 & 0.66 & 0.50 & 0.00 & & & \\
\hline FOM-16 & 0.61 & 0.50 & 0.69 & 0.44 & 0.49 & 0.00 & & \\
\hline FOM-20 & 0.68 & 0.42 & 0.55 & 0.49 & 0.45 & 0.47 & 0.00 & \\
\hline FOM-P22 & 0.69 & 0.49 & 0.61 & 0.58 & 0.52 & 0.44 & 0.45 & 0.00 \\
\hline
\end{tabular}

Fig.1 Wilted plants of Brinjal

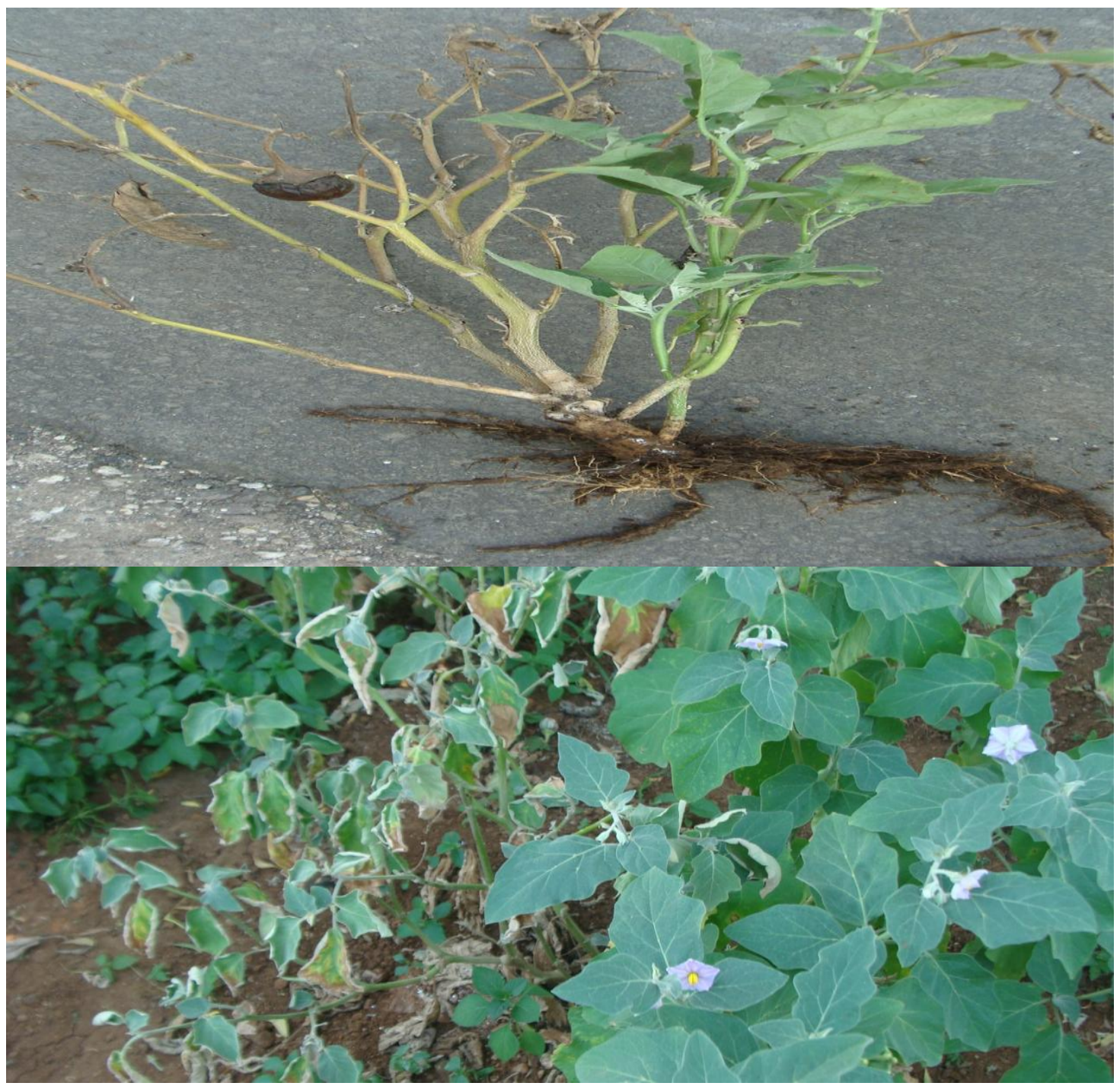


Fig.2 Pure cultures of Fusarium oysporum f.sp. melongenae collected from various regions of Marathwada

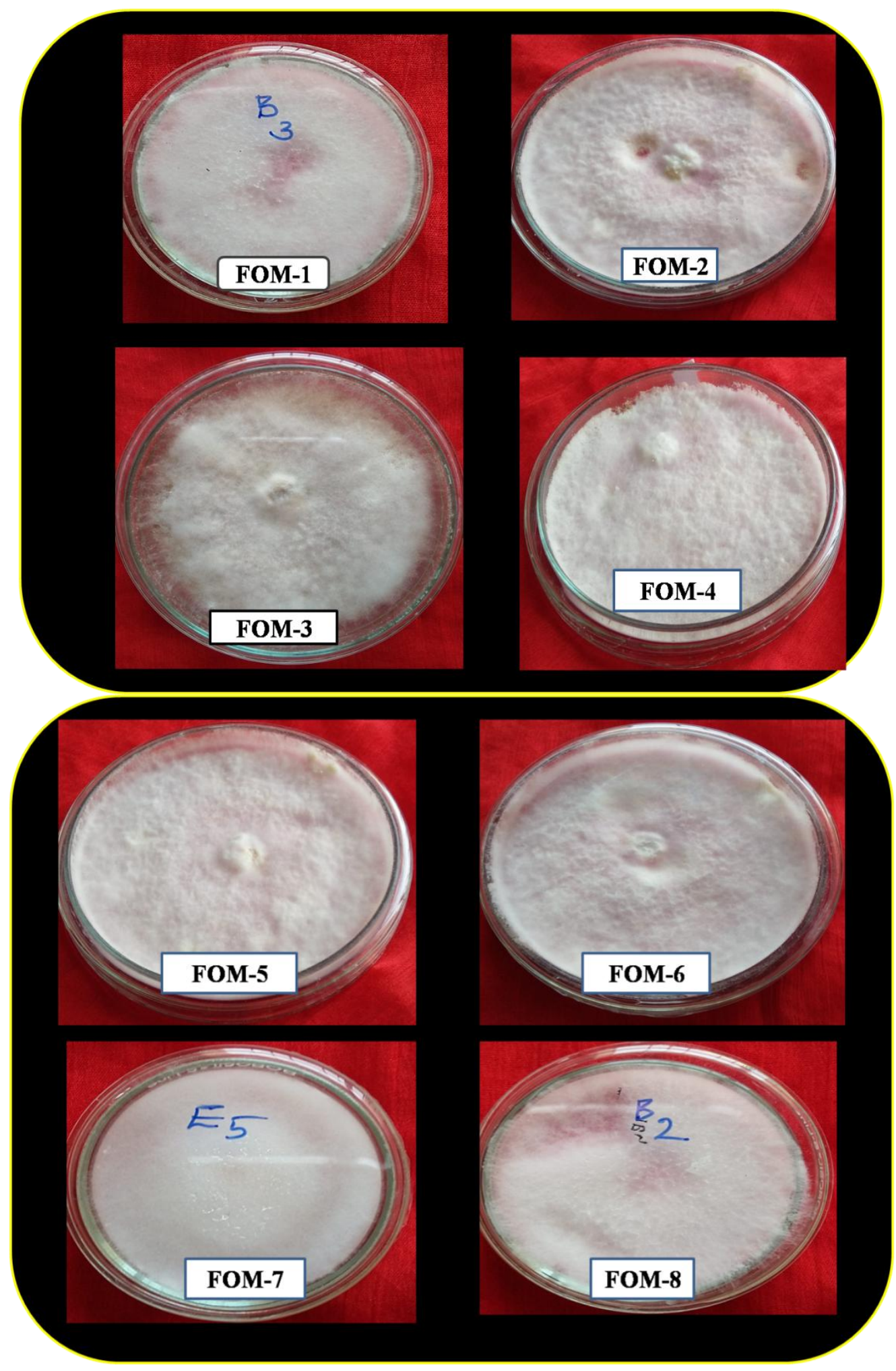


Fig.3 DNA was isolated from eight Fusarium oxysporum f.sp. melongenae

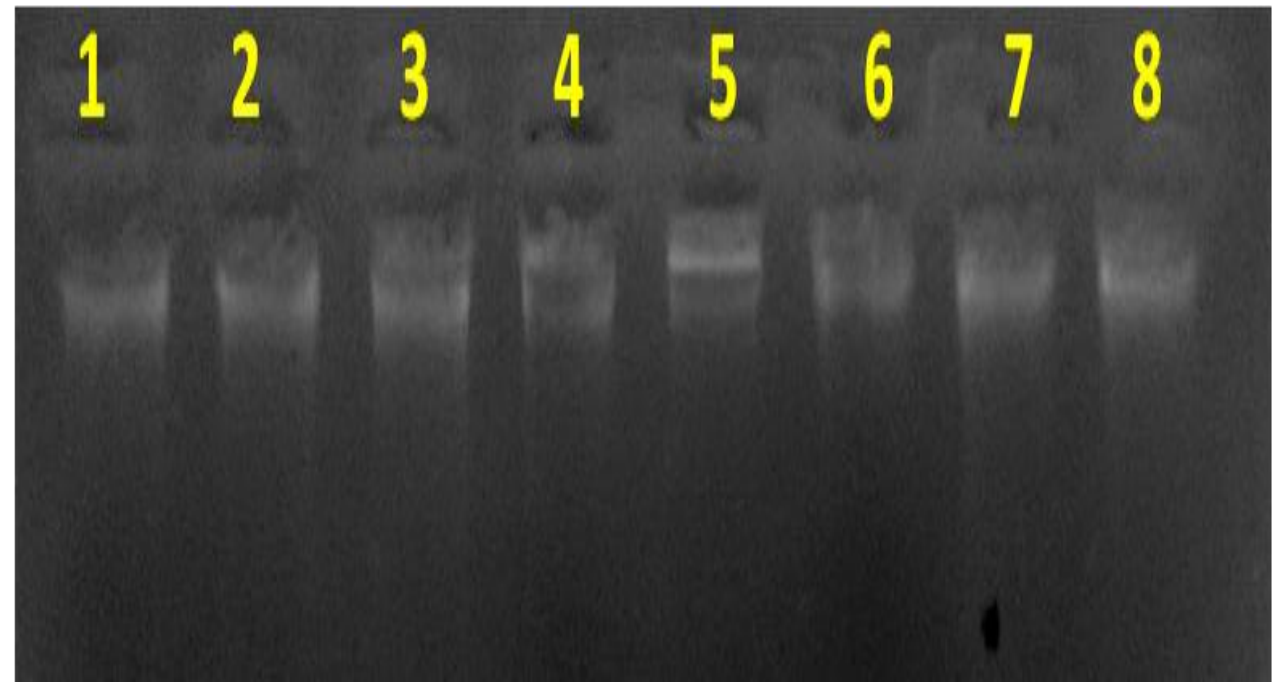

Fig.4 RAPD profile of FOM isolates generated by using primer OPA-16.

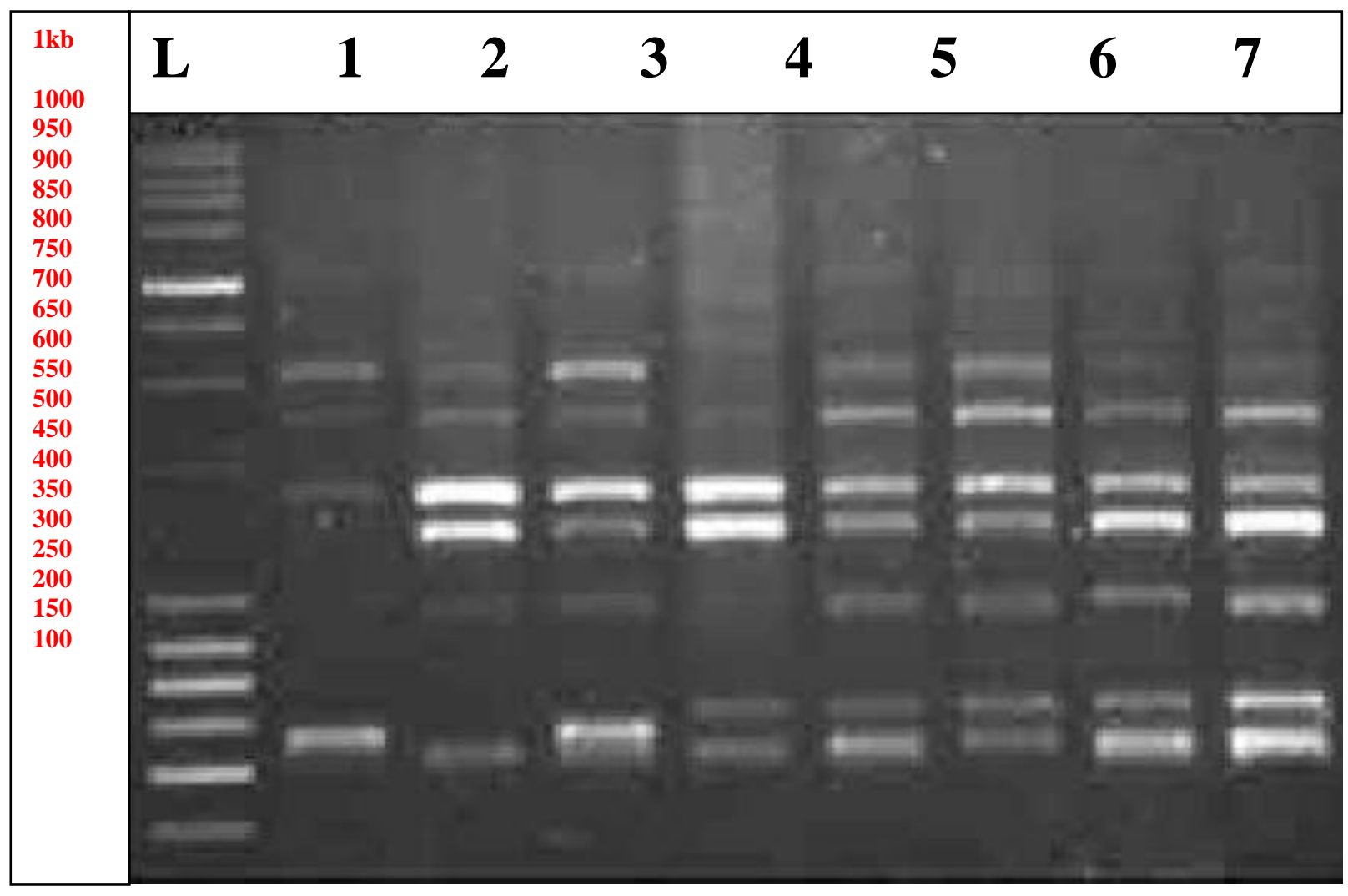


Fig.5 RAPD profile of FOM isolates generated by using primer OPA-10.

L-1kb DNA ladder; lane 1-8 FOM isolates described in table 1

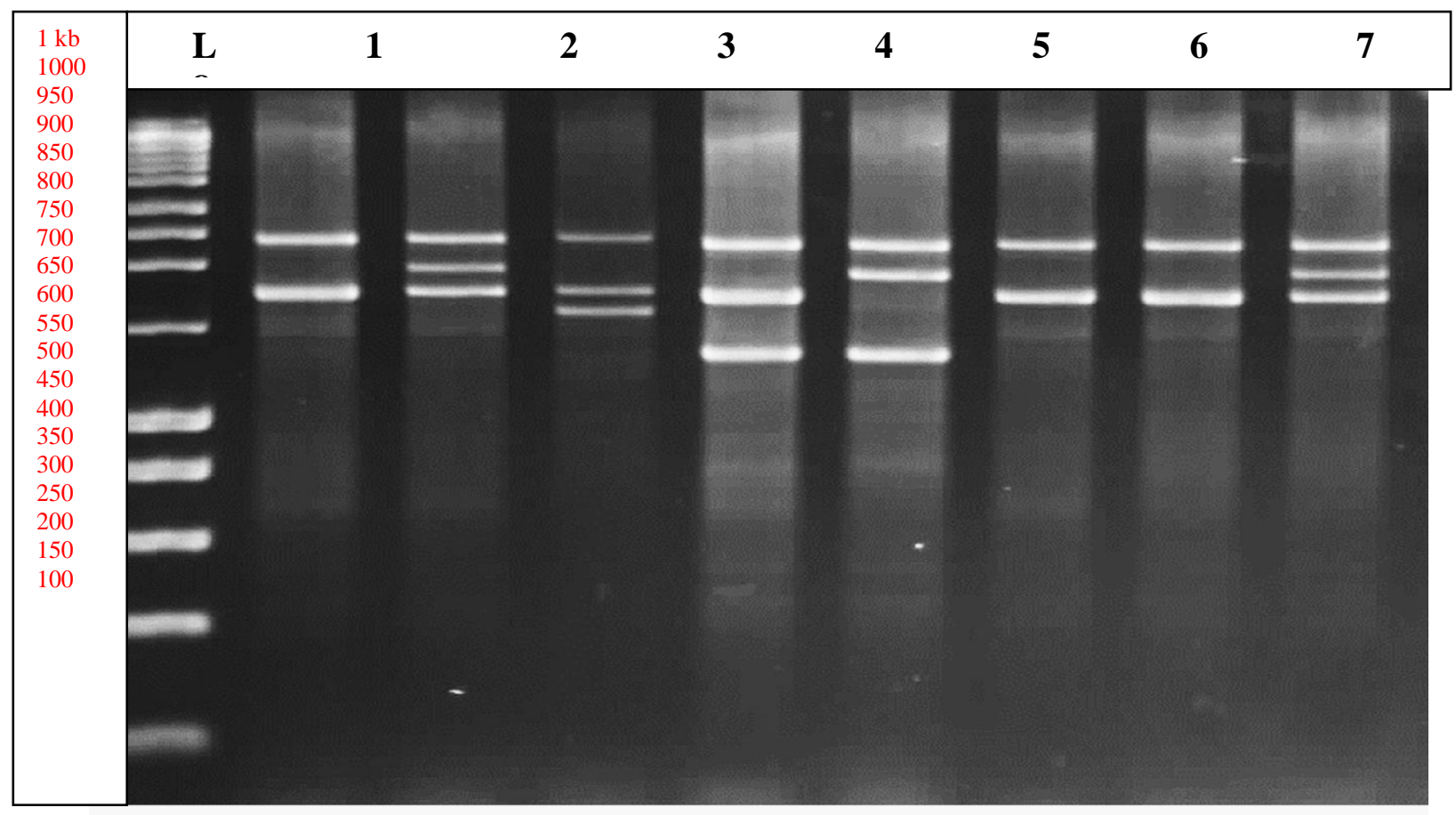

Fig.6 RAPD profile of FOM isolates generated by using primer OPA-12.

L- 1 kb DNA ladder lane 1-8 FOM isolates described in table 1

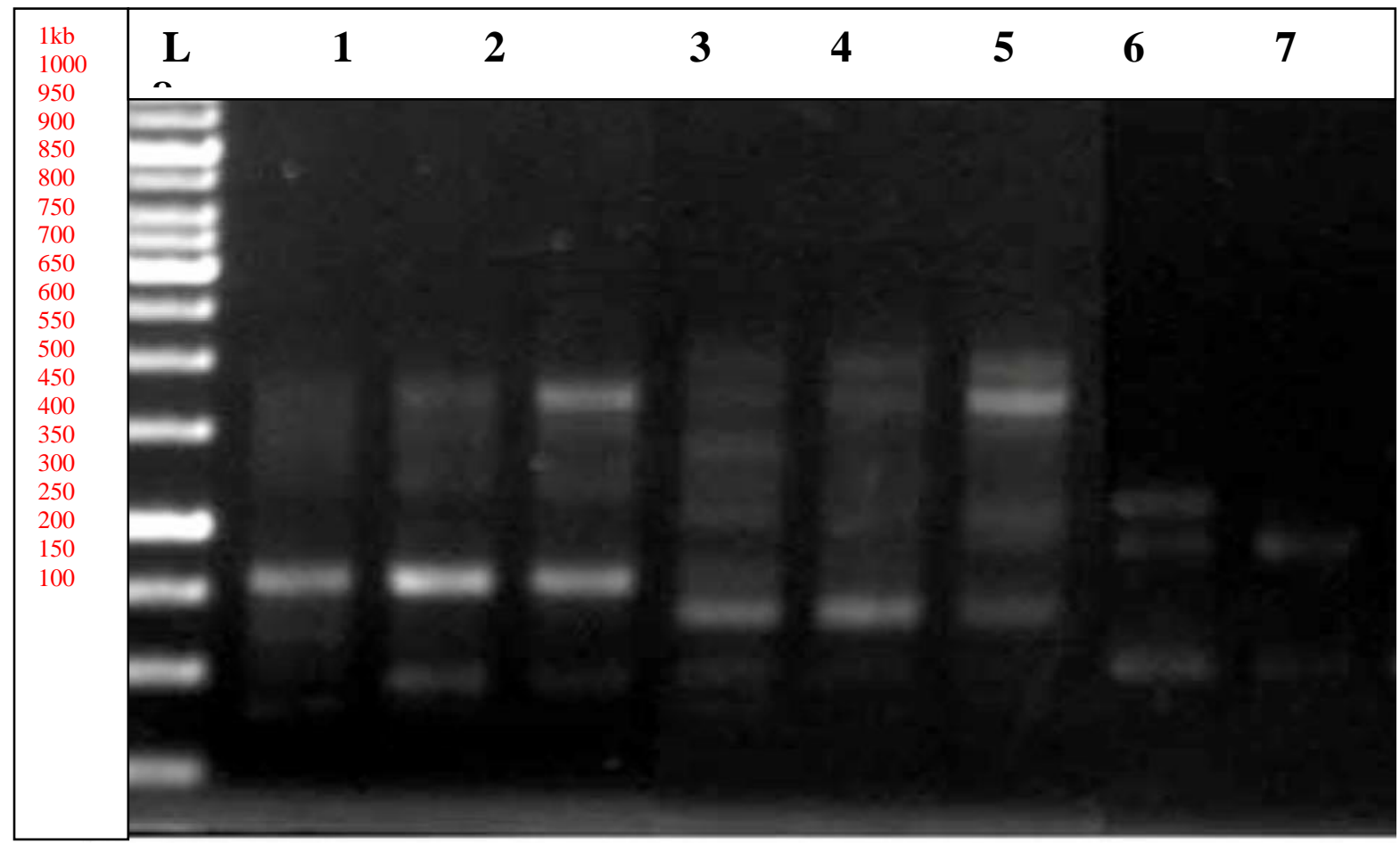


Fig.7 RAPD profile of FOM isolates generated by using primer OPA-06.

L-1kb DNA ladder; lane 1-8 FOM isolates described in table 1

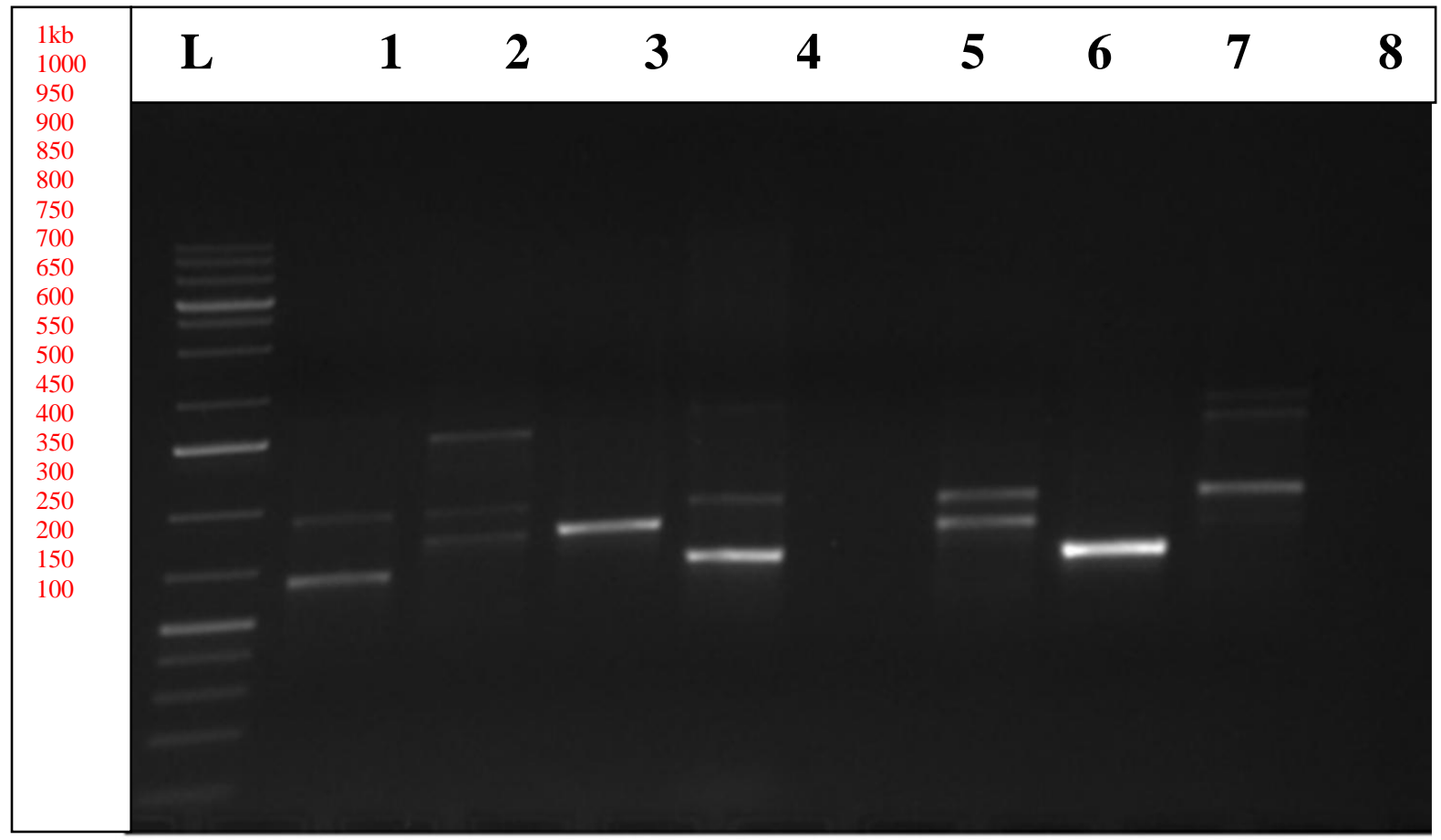

Fig. 8 RAPD profile of FOM isolates generated by using primer OPA-04

L-1kb DNA ladder; lane 1-8 FOM isolates described in table 1

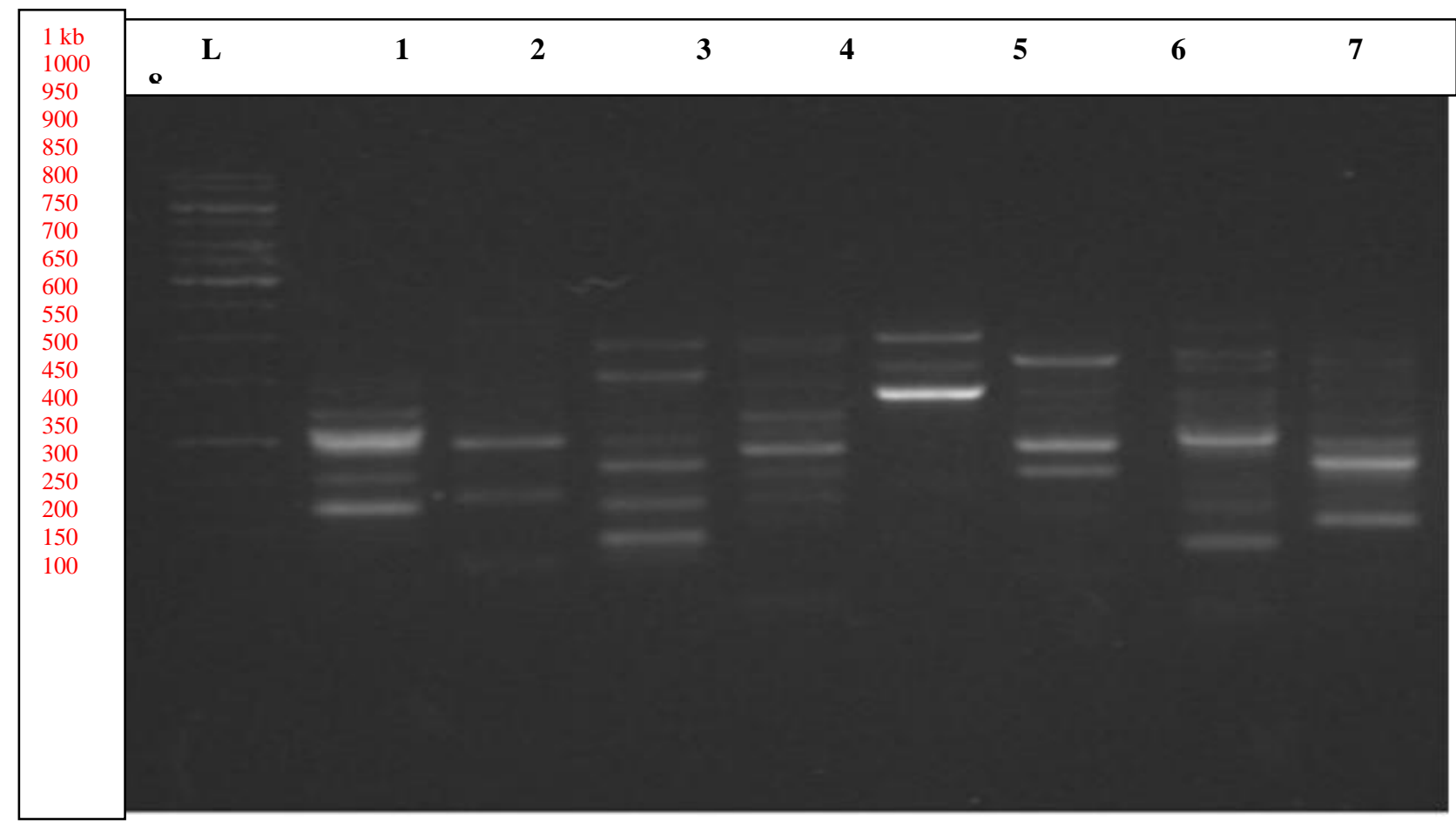


Fig.9 Dendrogram generated using NTSYS analysis demonstrating the relationship among eight FOM isolates

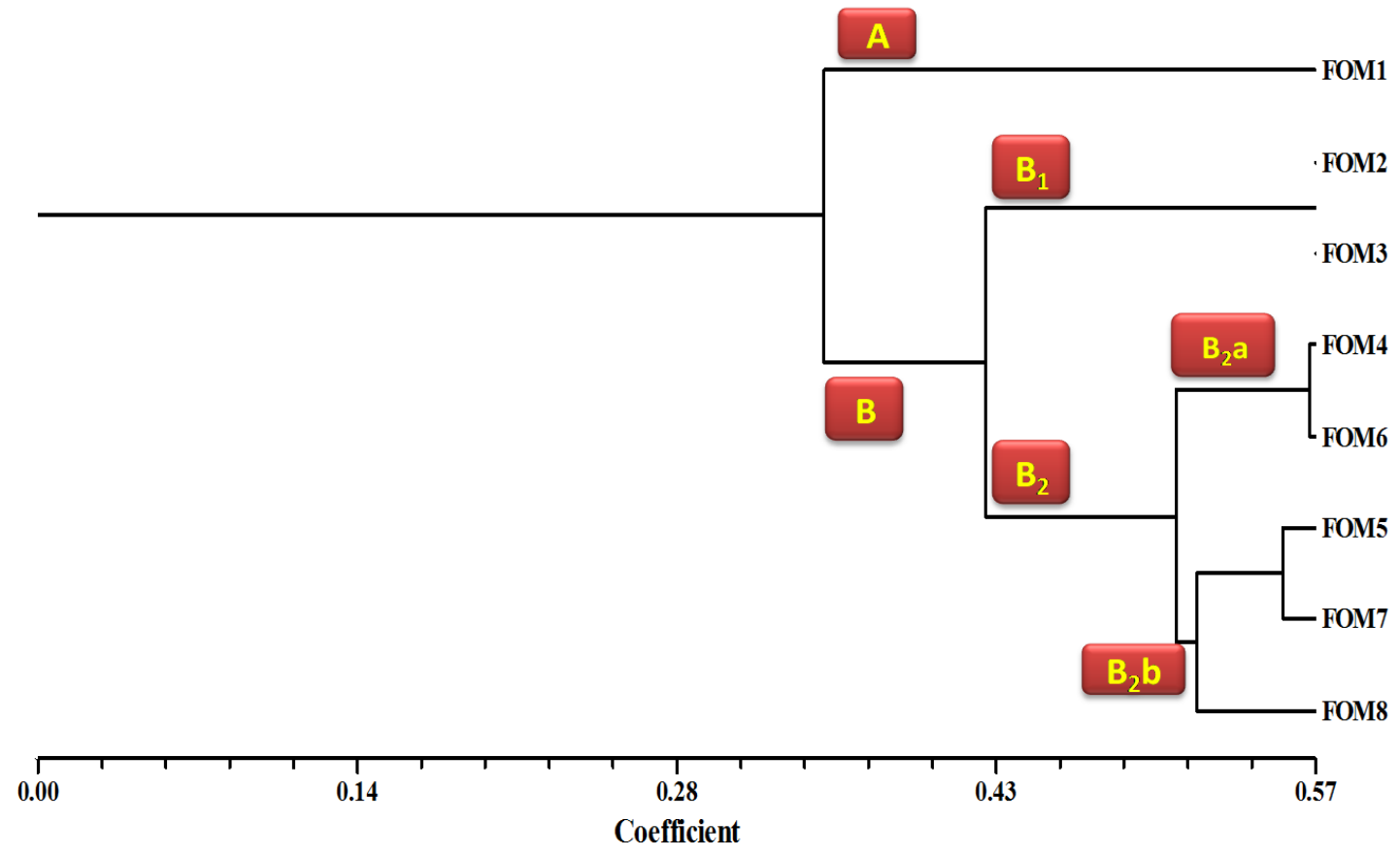

Genetic diversity analysis among eight FOM isolates based on dendrogram generated using RAPD Marker

Dendrogram was constructed on the basis of their variants from the entire data set of makers assisted identification and analysis of the 8 isolates of Fusarium oxysporum f. sp. melongenae.

Cluster based on RAPD marker analysis revealed the genetic distance ranged from 0.0 to 0.57 , which was used to generate the dendrogram by Jaccards coefficient of similarity \& UPGMA cluster analysis.

According to the cluster analysis, all the 8 FOM isolates were found distributed into 2 major cluster $\mathrm{A}$ and $\mathrm{B}$ at $35 \%$ similarity value. Cluster A contain only one isolates viz. FOM-1 at 35\% similarity. Of the entire cluster formed the largest one is cluster B having seven FOM isolates viz. FOM-2, FOM-3, FOM-4, FOM-6, FOM-5, FOM-7, and FOM-8. Cluster B is subdivided into cluster $\mathrm{B}_{1}$ and $\mathrm{B}_{2}$ at $42 \%$ similarity. Sub cluster $\mathrm{B}_{1}$ contain 2 isolates viz.FOM-2 and FOM-3 whereas sub cluster $\mathrm{B}_{2}$ contain 5 isolates viz. FOM-4, FOM-6, FOM-5, FOM7, and FOM-8.

Cluster $B_{2}$ is further divided into $B_{2} a$ and $B_{2} b$. Cluster $\mathrm{B}_{2}$ a comprises isolates FOM-4 and FOM-6 at $56 \%$ similarity. In cluster $\mathrm{B}_{2} \mathrm{~b} 3$ FOM isolates are included viz. FOM-5 FOM$7 \&$ FOM-8 at $51 \%$ similarity. Thus, in present studies molecular variability was observed among the isolates of Fusarium oxysporum f. sp. melongenae may be attributed to their geographic distribution in the Marathwada region of Maharashtra state, long term influence of weather parameters at a particular location and ability of the pathogen to adopt the chilli varieties grown.

Prasad et al., (2004) have reported 30-100 per cent genetic similarity among the isolates of $F$. oxysporum. The high polymorphism among the isolates may be due to the nucleotide alterations, insertions and deletions 
at initiation sites, recombination or gene flow, which may result in polymorphic DNA (Williams et al., 1990; Burdon and Silk, 1997; Kang et al., 2002). Previous studies by Kang et al., (2002) have indicated that the URP region in fungi is conserved and any change in the region may enable us to detect the variations at the interspecific and intraspecific levels. Some monomorphic bands are shared by all the isolates specific to particular species or specific to all the isolates of $F$. oxysporum and $F$. solani, which support the presence of certain gene/region in those isolates, which were responsible for their specific amplification to be separated into two different species. The clustering of the isolates in the UPGMA analyses was associated with the geographic localities from which the isolates were obtained but some isolates demonstrated variation to a particular locality. The observed deviations could be due to migration of conidia of the isolates through air/planting materials from one location to another. DNA banding pattern (DNA fingerprints) very specific to species $F$. oxysporum and/or $F$. solani obtained in the present study would be highly useful for rapid identification and differentiation of Fusarium isolates belonging to different species.

\section{References}

Bryan, G. T. and Daniels, M. J. (1995). Comparison of fungi within the Gaeumannomyces-Phialophora complex by analysis of ribosomal DNA sequence. Appl. Environ. Microbiology. 61: 681689.

Chaudhary, D.R. and Sharma, S.D. (2000). Screening of some brinjal cultivars against fusarium wilt and fruit borer. Agri. Sci. Digest, 20:129-130

Das, C.R. and Chattopathyay, S.B. 1953. Fusariums wilt on brinjal. Indian Phytopath. 8:130-135

Gardes, M. and Bruns, T. D. (1993). ITS primers with enhanced specificity for basidomycetes- application to the identification of mycorrhizae and rusts. Mol. Ecol. 2:113-118

Kalloo, G. and Berg, B.O. (1993). Genetic improvement of vegetable crops. Pergamon Press Ltd, Oxford UK, 587604.

Maria, S. B. and Urszula, J. (2012). Production of antifungal chitinase by Aspergillus niger LOCK 62 and its potential role in the biological control. Curr Microbiol. 65: 666-672

Mondal, B., Bhattacharya, I., Sarkar, A. and Khatua, D.S. (2013). Evaluation of local brinjal (Solanum melongena L.) germplasm for Fusarium resistance. Int. J. Agril. Stat. Sci., 9:709-716.

Nazar, R. N., Hu, X., Schmidt, J., Culham, D., Robb, J. (1991). Potential use of PCR amplified ribosomal intergenic sequence in the detection and differentiation of Verticillium wilt pathogens. Physiol. Mol. Plant Pathol. 39: 1-11.

O’Donnell, K. (1992). Ribosomal DNA internal transcribed spacers are highly divergent in the phytopathogenic ascomycetes Fusarium sambucinum (Gibberella pulicaris). Curr. Genet. 22: 213-220.

Rai, P.V., Shivappa Setty, K.K.A. and Vasantha Setty, K.P. (1975). Fusarium wilt of petunia and its source of inoculum. Curr. Res., 4: 173-174 12.

Rao, M.V.B., Sohi, H.S. and Vijay, O.P. (1976). Reaction of some varieties of brinjal to Pseudomonas solanacearum . Veg. Sci.,3:61-64

Rohlf, F.J. (1998). NTSYSpc. Numerical Taxonomy and Multivariate Analyses, Version 2.02i, Exeter Software, New York, USA

Sharma, B. K., Loganathan, M., Singh, R. P., Bag, T. K., Rai, R. K., Rai, A. B. and Rai, M. (2011). Aspergillus niger a potential biocontrol agent for controlling 
Fusarium wilt of tomato. Journal of Mycopathological Research. 49 (1):115118.

Sonoda, R.M. (1978). Effect of differences in tolerance of tomato to Pseudomonas solanacearum and time of planting on incidence of fusarium wilt. Pl. Dis. Rptr., 62:1059-1062

Zakir Hussain, M., Rahman, M.A. and Bashar, M.A. (2005). Screening of brinjal accessions for Fusarium wilt caused by Ralstonia solanacearum. Bangladesh $\mathrm{J}$. Bot. 34:53-58

Prasad, R.D., Sharma, T.R., Jana, T.K., Devi, T.P., Singh, N.K. and Koundal, K.R. (2004). Molecular analysis of genetic variability in Fusarium species using microsatellite markers. Indian Phytopathology, 57(3): 272-279.

Williams, J.G.K., Kubelic, A.R., Livak, K.J., Rafalski, J.A. and Tingey, S.V. (1990). DNA polymorphisms amplified by arbitrary primers are useful as genetic markers. Nucleic Acids Research, 18: 6531-6535.

Burdon, J.J. and Silk, J. (1997). Sources and patterns of diversity in plant-pathogenic fungi. Phytopathology, 87: 664-669.

Khan, M.A. and Zhihui, C.H. (2010). Influence of garlic root exudates on cytomorphological alteration of the hyphae of Phytophthora capsici, the cause of Phytophthora blight in pepper. Pakistan Journal of Botany, 42(6): 4356-4361.

Harish D. K., Agasimani, A. K., Imamsaheb S. J. and Patil Satish S. 2011. Growth and yield parameters in brinjal as influenced by organic nutrient management and plant protection conditions. Research Journal of Agricultural Sciences, 2(2): 221-225.

Sihachakr D, Daunay M C, Serraf I, Chaput M H, Mussio I, Haicour R, Rossignol L, Ducreux G (1994). Somatic hybridization of eggplant with its close and wild relatives. In: Bajaj YPS (ed) Biotechnology in agriculture and forestry, somatic hybridization in crop improvement, Springer-Verlag, Berlin. 255-278 pp.

Jaworski, C.A. and Morton, D.J. 1964. An epiphytotic of Pseudomonas solanacearum in tomatoes on newlyclearedKlej sand in relation to potassium, calcium, and magnesium levels. Pl. Dis. Rep., 48: 88-89.

Sonoda, R.M. 1978. Effect of differences in tolerance of tomato to Pseudomonas solanacearum and time of planting on incidence of fusarium wilt. Pl. Dis. Rptr., 62: 1059-1062.

Jmenez-Gasco M, Perez-Artes E, JimenezDiaz RM. (2001) Identifi-cation of pathogenic races $0,1 \mathrm{~B} / \mathrm{C}, 5$, and 6 of Fusarium oxysporum f. sp. ciceris with random amplified polymorphic DNA(RAPD). Eur J Plant Pathol., 107: 237-248.

Rohlf FI. N tsys-pc. Numerical taxonomy and multivariate analysis system Version 2.0. Applied Biostatistics, New York, USA, Exeter Software, 1990.

\section{How to cite this article:}

Govardhan Rao, V., S.R. Bhalerao, D.N. Dhutraj, S.R. Bhalerao2, K.T. Apet, C.V. Ambadkar, B. Prasanna Kumar, A. T. Daunde, P.L. Sontakke and Patil, A.G. 2019. Investigation of Genetic Diversity in Fusarium Wilt of Egg Plant Caused by Fusarium oxysporum f.Sp. melangene (Schlecht) Mutuo and Ishigami in Marathwada Region of Maharastra. Int.J.Curr.Microbiol.App.Sci. 8(07): 1079-1093. doi: https://doi.org/10.20546/ijcmas.2019.807.129 